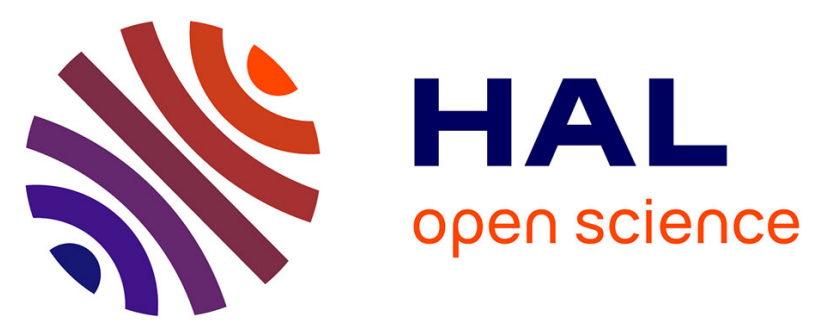

\title{
Di(p-methoxyphenyl)amine end-capped tri(p-thiophenylphenyl)amine based molecular glasses as hole transporting materials for solid-state dye-sensitized solar cells
}

Thanh-Tuan Bui, Said Karim Shah, Xavier Sallenave, Mamatimin Abbas, Gjergji Sini, Lionel Hirsch, Fabrice Goubard

\section{To cite this version:}

Thanh-Tuan Bui, Said Karim Shah, Xavier Sallenave, Mamatimin Abbas, Gjergji Sini, et al.. Di(pmethoxyphenyl)amine end-capped tri(p-thiophenylphenyl)amine based molecular glasses as hole transporting materials for solid-state dye-sensitized solar cells. RSC Advances, 2015, 5 (61), pp.4959049597. 10.1039/c5ra07226c . hal-01534909

\author{
HAL Id: hal-01534909 \\ https://hal.science/hal-01534909
}

Submitted on 8 Jun 2017

HAL is a multi-disciplinary open access archive for the deposit and dissemination of scientific research documents, whether they are published or not. The documents may come from teaching and research institutions in France or abroad, or from public or private research centers.
L'archive ouverte pluridisciplinaire HAL, est destinée au dépôt et à la diffusion de documents scientifiques de niveau recherche, publiés ou non, émanant des établissements d'enseignement et de recherche français ou étrangers, des laboratoires publics ou privés. 


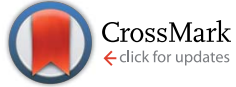

Cite this: RSC Adv., 2015, 5, 49590

Received 21st April 2015 Accepted 28th May 2015

DOI: $10.1039 / c 5 r a 07226 c$

www.rsc.org/advances

\section{Di(p-methoxyphenyl)amine end-capped tri(p- thiophenylphenyl)amine based molecular glasses as hole transporting materials for solid-state dye- sensitized solar cells $\dagger$}

\author{
Thanh-Tuân Bui, ${ }^{\text {a }}$ Said Karim Shah, ${ }^{\text {bcd }}$ Xavier Sallenave, ${ }^{a}$ Mamatimin Abbas, ${ }^{\text {bc }}$ \\ Gjergji Sini, ${ }^{a}$ Lionel Hirsch ${ }^{\star b c}$ and Fabrice Goubard ${ }^{\star a}$
}

Three tris(thienylphenyl)amine-based molecular glass hole transporting materials were synthetized, characterized and incorporated in solid state dye-sensitized solar cells. Devices using these compounds as solid hole conductors show relatively high $V_{\text {oc }}$ thanks to good energy level matching between them and the associated D102 indoline dye. However, they yield relatively low $J_{\text {sc }}$ and FF compared to SpiroOMeTAD based control devices, which is due to an order of magnitude lower conductivity with respect to Spiro-OMeTAD. Maximum solar-to-electrical energy conversion efficiencies of $1.2 \%$ under standard illumination condition was obtained. Stability tests of unsealed devices in air under continuous illumination have been performed and devices based on new compounds have kept up to $80 \%$ of their initial efficiency.

\section{Introduction}

In recent years, the development of small molecules for photovoltaic devices has received considerable interest. A huge number of molecules have been designed, synthetized, and characterized for use as active materials in organic solar cells ${ }^{1}$ or as hole transporting materials (HTMs) in hybrid organic-inorganic photovoltaics. ${ }^{2-4}$ Compared to polymers, small molecules exhibit many outstanding advantages such as structural versatility, unique molecular weight as well as relatively easy purification processes. Despite their tendency to crystallization, small molecules can form stable amorphous materials above ambient temperature if their structures are meticulously designed. ${ }^{5}$ The most successful molecular HTM is $2,2^{\prime}, 7,7^{\prime}$-tetrakis( $N, N$-di-4methoxyphenyl-amine)-9,9'-spirobifluorene (Spiro-OMeTAD) which was firstly reported by Grätzel et al. in $1998 .^{6}$ To date, the Spiro-OMeTAD based cell efficiencies have been higher than $7 \%$ after optimizing doping conditions by cobalt complex and in combination with high molar extinction coefficient organic dyes. ${ }^{7}$ Using perovskite as light harvester, Spiro-OMeTAD based

\footnotetext{
${ }^{a}$ Laboratoire de Physicochimie des Polymères et des Interfaces (LPPI), Université de Cergy-Pontoise, 5 mail Gay Lussac, Neuville-sur-Oise, 95031 Cergy-Pontoise Cedex, France.E-mail: tbui@u-cergy.fr; fabrice.goubard@u-cergy.fr

${ }^{b}$ Univ. Bordeaux, IMS, UMR 5218, F-33607 Pessac, France. E-mail: lionel.hirsch@ ims-bordeaux.fr

${ }^{c}$ CNRS, IMS, UMR 5218, F-33607 Pessac, France

${ }^{d}$ Department of Physics, Abdul Wali Khan University, Mardan, Khyber Pakhtunkhwa, 23200 Pakistan
}

$\dagger$ Electronic supplementary information (ESI) available. See DOI: $10.1039 / \mathrm{c} 5 \mathrm{ra} 07226 \mathrm{c}$ cells have shown impressive efficiencies, ${ }^{8}$ even reaching $20.1 \%$ as confirmed in November 2014 by NREL. The success of SpiroOMeTAD is due to its stable amorphous film (relative high glass transition temperature), relative high solubility, appropriate oxidation potential versus light harvesting materials (dyes or perovskites), and transparency in the visible spectrum with no absorption screen effect compared to dye. Despite offering the best performance yet achieved in a molecular hole conductor based cell, Spiro-MeOTAD suffers from a relatively low hole mobility. ${ }^{7,9}$ Novel HTMs other than Spiro-OMeTAD have also been investigated and most of them are amine related compounds, ${ }^{4,10,11}$ exhibiting suitable electrochemical oxidation potentials, good charge transport, good thermal and morphological stability. Only few examples of successful non-amine derivative HTMs have been reported, ${ }^{12}$ Among amine derivatives, triphenylamines (TPA) having pseudo-3D conjugated architecture constitutes an attractive class of materials..$^{13}$ Recently, we have reported on several series of star-shaped TPA based materials., ${ }^{2,14}$ Combined experimental and theoretical studies have shown that these molecular glasses have suitable characteristics for use as HTM in solid-state DSSCs. ${ }^{15}$

In the present work, we report the design, synthesis and photovoltaic properties of new star-shaped p-type amorphous organic semiconductors based on tris(4-(thiophen-2-yl)phenyl) amine cores (Fig. 1). Methyl moiety has been added in the thiophene ring to increase the dihedral angles between the adjacent rings, reducing the $\pi$-conjugation pathway and leading to blueshifts in optical absorption. Each arm of these molecules is end-capped by a di(4-methoxyphenyl)amino moiety. These electron rich end-capping groups will be seen to modulate 


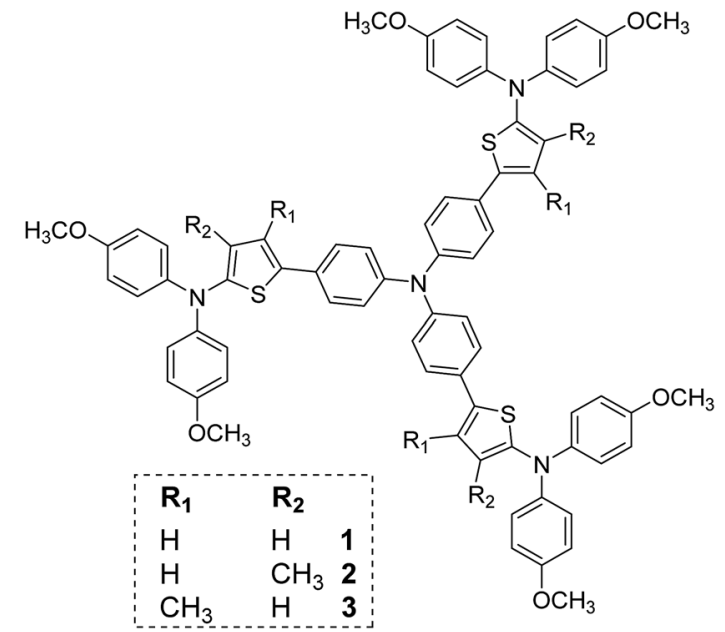

Fig. 1 Molecular structures of 1-3.

electrochemical properties of targeted compounds. Methoxy groups enhance pore filling properties of these molecules by (i) rendering them more soluble in organic solvents and (ii) making them more hydrophilic and increasing dye-sensitized $\mathrm{TiO}_{2} / \mathrm{HTM}$ affinity. Additionally, the presence of methoxy groups in para positions of phenyl rings of the diphenylamino moiety has been shown to favor charge transport properties. ${ }^{16}$ We have incorporated these molecules as HTMs in solid state D102-sensitized DSSC. The photovoltaic performances of obtained devices will be presented and discussed.

\section{Results and discussion}

\subsection{Synthesis}

The synthetic route toward studied compound is outlined in Fig. 2. Compounds $\mathbf{1}$ and $\mathbf{3}$ were obtained as reported in our preliminary work. ${ }^{2}$

$N$-(3-Methyl-2-thiophenyl)- $N, N$-di(4-methoxyphenyl)amine 6 was obtained from the Pd-catalyzed amination of 2-bromo-3methylthiophene ${ }^{2}$ and di(4-methoxyphenyl)amine. 6 was then subjected to a brominating reaction leading to 6-Br. Finally, 2 was constructed from tris(4-(4,4,5,5-tetramethyl-[1,3,2]dioxaborolane)phenyl)amine ${ }^{2}$ and $6-\mathrm{Br}$ by means of a threefold Suzuki cross-coupling reactions. Structures of intermediates and final compounds were fully elucidated by NMR and mass spectrometry. As expected, 1-3 have good solubility in common solvents such as dichloromethane, chlorobenzene, toluene, etc. Their good solubility renders them suitable for solution processing of electronic devices.

\subsection{Thermal properties}

Thermal properties of 1-3 were investigated by thermogravimetric analysis (TGA) and differential scanning calorimetry (DSC) ${ }^{17}$ under argon atmosphere. The TGA and DSC curves of 13 are shown in ESI (Fig. S1 $\dagger$ ). The thermal decomposition $\left(T_{\mathrm{d}}\right)$ and the glass transition $\left(T_{\mathrm{g}}\right)$ temperatures were summarized in Table 1. Synthesized compounds showed significant thermal stability with $T_{\mathrm{d}}$ values superior to $300{ }^{\circ} \mathrm{C}$ which are high enough for the applications in optoelectronic devices. Glass forming properties of 1-3 were revealed by DSC. They were obtained as amorphous materials as confirmed by DSC. All compounds exhibit relatively high glass transition temperatures $\left(T_{\mathrm{g}}\right)$ ranging from 74 to $99{ }^{\circ} \mathrm{C} .1$ exhibits the highest glass transition at $99^{\circ} \mathrm{C}$. The introduction of a methyl moiety on the outer position of thiophene ring (against triphenylamine core) does not affect the thermal properties of resulting molecules 2 $\left(T_{\mathrm{g}}=96^{\circ} \mathrm{C}\right)$. However, the methyl moiety on the inner position of thiophene ring (molecule 3) significantly decreases thermal stability ( $T_{\mathrm{d}}$ of $\mathbf{3}$ is lower by $115{ }^{\circ} \mathrm{C}$ than that of $\left.\mathbf{1}\right)$ and glass transition temperature $\left(T_{\mathrm{g}}=74^{\circ} \mathrm{C}\right)$. This trend was confirmed by comparative TGA analysis of corresponding precursors $\mathbf{5}\left(T_{\mathrm{d}}\right.$ $\left.=373{ }^{\circ} \mathrm{C}\right)$ and $7\left(T_{\mathrm{d}}=287^{\circ} \mathrm{C}\right)$.

\subsection{Geometry and electronic properties of compounds 1-3}

The geometries of compounds $\mathbf{1 - 3}$ are shown in Fig. 3 . The methyl substituents in $\mathbf{2}$ and $\mathbf{3}$ are found to increase the dihedral angles between the adjacent rings by roughly $17^{\circ}$ (from

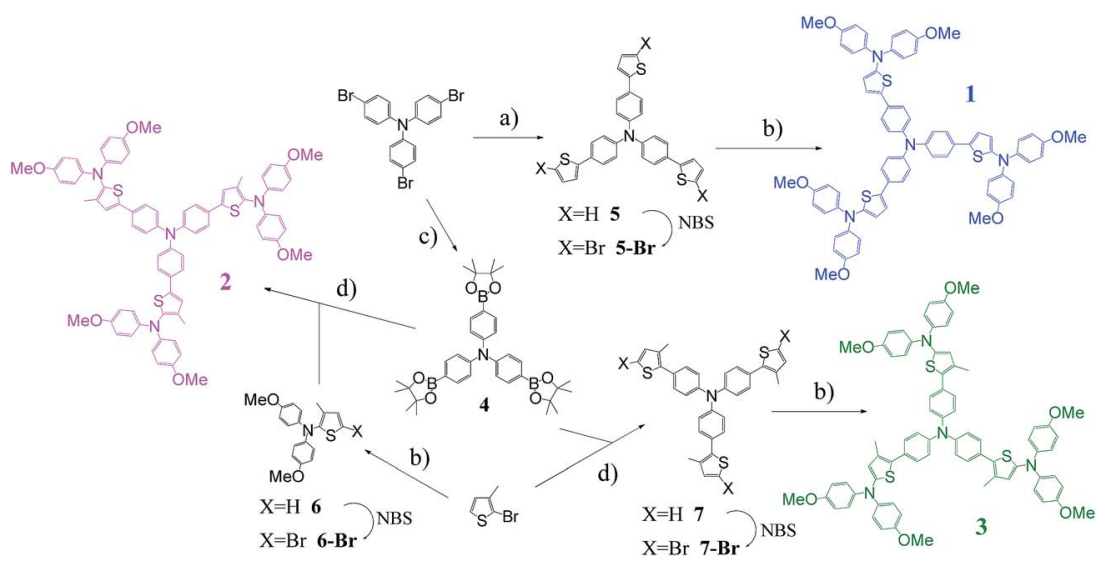

Fig. 2 Synthesis of 1, 2 and 3. Reagents and conditions: (a) 2-(tributylstannyl)thiophene, $\mathrm{Pd}\left(\mathrm{PPh}_{3}\right)_{4}$, toluene, $120^{\circ} \mathrm{C}, 16 \mathrm{~h}$. (b) 4,4'-Dimethoxydiphenylamine, $\mathrm{NaO}{ }^{t} \mathrm{Bu}, \mathrm{Pd}(\mathrm{dba})_{2}, \mathrm{P}\left({ }^{\mathrm{t}} \mathrm{Bu}\right)_{3}$, toluene, $100^{\circ} \mathrm{C}, 72 \mathrm{~h}$. (c) 2-Isopropoxy-4,4,5,5-tetramethyl-1,3,2-dioxaborolane, $n$-BuLi, $-78{ }^{\circ} \mathrm{C}, \mathrm{THF}$, 16 h. (d) $\mathrm{Pd}\left(\mathrm{PPh}_{3}\right)_{4}, \mathrm{~K}_{2} \mathrm{CO}_{3} 2 \mathrm{M}$, Aliquat 336, toluene, $90{ }^{\circ} \mathrm{C}, 72 \mathrm{~h}$. 
Table 1 Thermal, optical and electrochemical properties of investigated HTMs and that of D102 dye. The HOMO and LUMO energies (B3LYP/6$31 \mathrm{G}(\mathrm{d}, \mathrm{p})$ energies are given in parentheses)

\begin{tabular}{|c|c|c|c|c|c|c|c|c|c|c|}
\hline Compd & $\begin{array}{l}\mathrm{MW}, \\
\mathrm{g} \mathrm{mol}^{-1}\end{array}$ & $T_{\mathrm{g}}{ }^{a},\left({ }^{\circ} \mathrm{C}\right)$ & $T_{\mathrm{d}}^{b},\left({ }^{\circ} \mathrm{C}\right)$ & $\begin{array}{l}\lambda_{\max } \\
\text { (solid), } \mathrm{nm}\end{array}$ & $\begin{array}{l}\lambda_{\max } \\
\text { (solution) }\end{array}$ & $\lambda_{\text {onset }}{ }^{c}, \mathrm{~nm}$ & $E_{\text {gap }}^{\mathrm{opt} d}, \mathrm{eV}$ & $\begin{array}{l}E_{\mathrm{Oxi}}^{\text {Onsete }}, \\
\left(\mathrm{V} / \mathrm{Fc}^{+} / \mathrm{Fc}\right)\end{array}$ & $\begin{array}{l}\mathrm{IP}^{\mathrm{SS}} \\
\left(\varepsilon_{\text {номо }}\right)^{f},(\mathrm{eV})\end{array}$ & $\begin{array}{l}\mathrm{EA}^{\mathrm{SS}} \\
\left(\varepsilon_{\text {LUMO }}\right)^{g},(\mathrm{eV})\end{array}$ \\
\hline 1 & 1173.47 & 99 & 428 & 420 & 406 & 449 & 2.76 & 0.07 & $4.87(-4.36)$ & $2.11(-1.09)$ \\
\hline 3 & 1215.54 & 74 & 313 & 389 & 382 & 435 & 2.85 & 0.1 & $4.90(-4.39)$ & $2.05(-0.93)$ \\
\hline D102 & & & & & 490 & 556 & 2.23 & 0.29 & 5.09 & 2.86 \\
\hline
\end{tabular}

${ }^{a}$ Determined from DSC analyses in argon at heating rate: $20^{\circ} \mathrm{C} \mathrm{min}^{-1} \cdot{ }^{b} 5 \%$ weight loss in TGA analyses in argon at heating rate: $20{ }^{\circ} \mathrm{C}$ min ${ }^{-1} \cdot{ }^{c}$ In dilute THF solution. ${ }^{d} E_{\mathrm{g}}^{\mathrm{opt}}=h c / \lambda_{\text {onset }}=1240 / \lambda_{\text {onset }}{ }^{e}$ In dichloromethane solution containing $\mathrm{TBAPF}_{6}$ as supporting electrolyte $(0.1 \mathrm{M}), 100 \mathrm{mV} \mathrm{s}{ }^{-1}$. ${ }^{f} \mathrm{IP}^{\mathrm{SS}}=\left(E_{\mathrm{Oxi}}^{\text {Onset }}+4.8\right) \cdot{ }^{g} \mathrm{EA}^{\mathrm{SS}}=\mathrm{IP}^{\mathrm{SS}}-E_{\mathrm{g}}^{\text {opt }}$.

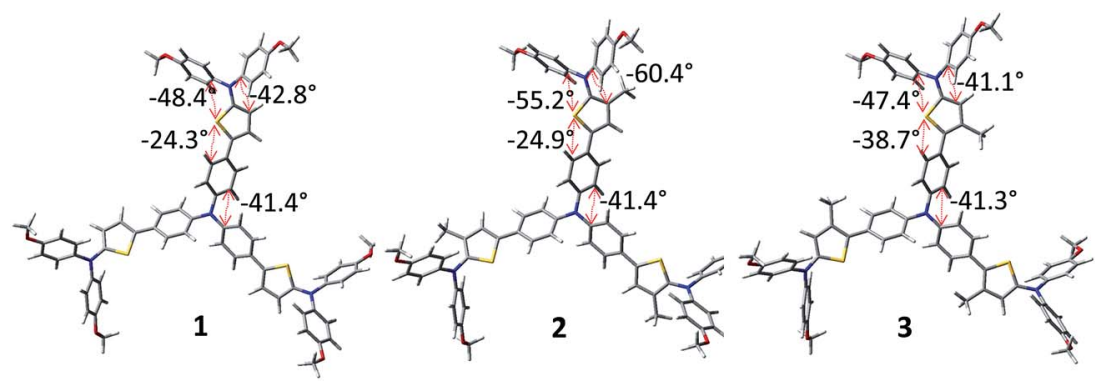

Fig. 3 Geometry of compounds 1-3 obtained at the B3LYP/6-31G(d,p) level in "gas phase". A selection of dihedral angles is shown.

$42.8^{\circ}$ to $60.4^{\circ}$ ) and $14^{\circ}$ (from $24.9^{\circ}$ to $38.7^{\circ}$ ) respectively, as compared to 1 . However, increasing the steric hindrance in the middle of the conjugated backbone of each arm (compound 3) is expected to prevent to a larger degree from a compact packing as compared to the positioning of methyl groups at the end of the arms (compound 2), where some steric hindrance is already present, this difference might be at the origin of the lower $T_{\mathrm{g}}$ value of compound 3 as compared to 1 and 2 .

A selected set of MOs corresponding to compounds 1-3 are shown in Fig. 4. In the three cases, the HOMOs are localized in the TPA and thiophene rings, exhibiting very small contributions from the DPA groups. These HOMO distribution patterns, along with the general geometrical shape of compounds 1-3 will be seen to strongly impact the charge-transport properties of these molecules.

HOMO and LUMO energies are given in Table 1. Due to the larger size of the lobes on the LUMOs as compared to HOMOs, the thiophene methylation in the proximity of the TPA phenyl groups results in strong destabilization of the LUMO of 3 as compared to $\mathbf{1}$ (decrease in $\pi$-conjugation efficiency at the

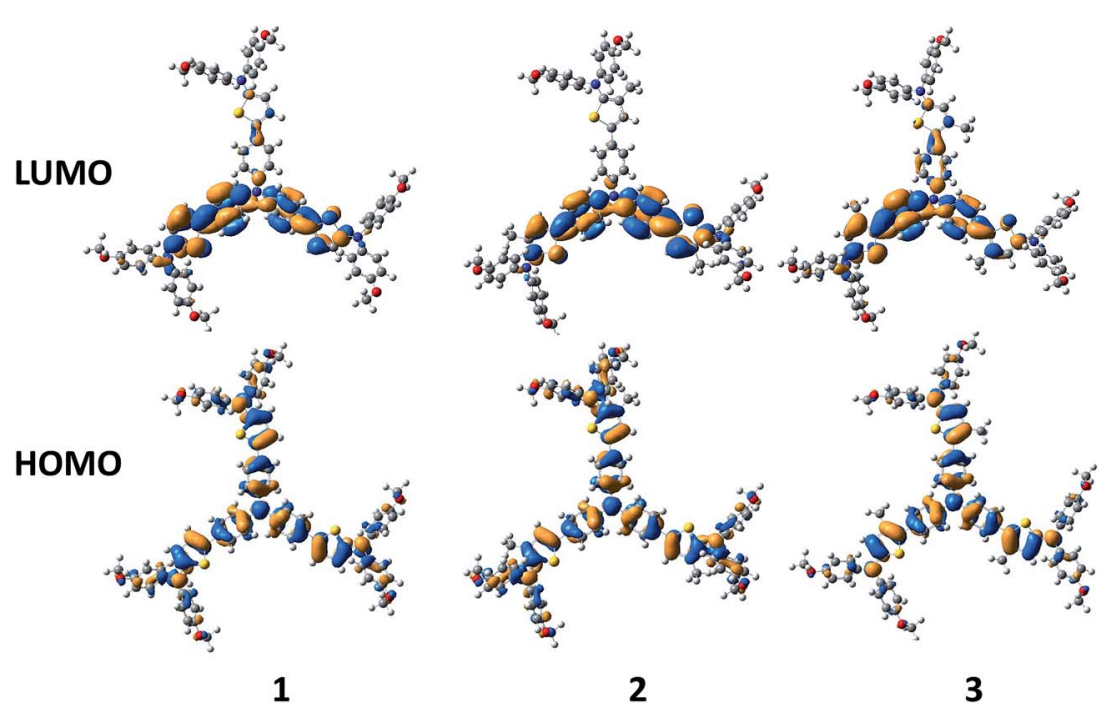

Fig. $4 \mathrm{HOMO}$ and LUMO pictograms corresponding to compounds 1-3 (B3LYP/6-31G(d,p) level). 
$\mathrm{Ph}-\mathrm{Th}$ junction), and in slight stabilization of the HOMO (decrease of HOMO anti-bonding character at the $\mathrm{Ph}-\mathrm{Th}$ junction). Inspection of HOMO and LUMO of 1, indicates stabilization for both orbitals upon thiophene methylation near the DPA position (compound 2 with respect to $\mathbf{1}$ ).

\subsection{Electrochemical and optical properties}

Cyclic voltammetry has been employed to investigate the redox behavior of synthesized molecules and to estimate the ionization potential $\left(\mathrm{IP}^{\mathrm{SS}}\right)$ and electron affinity $\left(\mathrm{EA}^{\mathrm{SS}}\right)$, which, in view of Koopmans' theorem, are good approximations of the HOMO and LUMO energy respectively. The cyclic voltammograms of 13 showing their first oxidations are shown on Fig. S2 in the ESI $\dagger$ and related data is summarized in Table $1 . \mathrm{IP}^{\mathrm{SS}}$ and $\mathrm{EA}^{\mathrm{SS}}$ values were estimated by using the ferrocene $(\mathrm{Fc})$ ionization potential value ( $4.8 \mathrm{eV} v s$. vacuum) as the standard. The first oxidation potentials could be attributed to the formation of radical cation of the triphenylamine core. These compounds have onset oxidation potentials of approximately $0.1 \mathrm{~V} / \mathrm{Fc}^{+} / \mathrm{Fc}$, which could match with the $\mathrm{D} 102$ dye $\left(0.29 \mathrm{~V} / \mathrm{Fc}^{+} / \mathrm{Fc}\right)$. The $\mathrm{IP}^{\mathrm{SS}}$ values determined from the oxidation onset potential values of 1-3 with respect to $\mathrm{Fc}^{+} / \mathrm{Fc}$ range between 4.87 and $4.92 \mathrm{eV}$. Compared to the $\mathrm{IP}^{\mathrm{SS}}$ of D102 dye (5.09 eV, Table 1) sufficient driving force for hole injection from D102 to the HTM can be deduced $(0.22,0.17$, and $0.19 \mathrm{eV}$ respectively for 1-3). This suggests that 1-3 could be potential HTM in D102-sensitized solar cells.

Optical properties of 1-3 were examined in dilute THF solutions and in thin film solid state. UV-vis absorption spectra were given in Fig. 5 and related data are summarized in Table 1. Absorption of indoline dye (D102) used in the present work as light harvester in DSSC devices were also given for comparison purpose.

All compounds have similar optical behaviors in dilute solution. They have a strong absorption band located in the UV/near visible spectral domain (375-425 $\mathrm{nm})$. Theoretical absorption spectra (Fig. S3 $\uparrow$ ) indicate that the intense low energy band is due to HOMO $\rightarrow$ LUMO, LUMO+1 transitions. In the case of compound 3 , the introduction of methyl group into the thiophene ring near the TPA moiety results in increased $\mathrm{Ph}-$ Th dihedral angle (Fig. 3 ) and decreased of $\pi$-conjugation efficiency. Compared to compound 1 , the decreased HOMO energy and the increased LUMO energy of compound 3 (Table 1) result in gap opening and blue-shift of the absorption band. Smaller gap opening in the case of compound 2 results in smaller absorption blueshift as compared to 1 . The optical band gaps $\left(E_{\mathrm{g}}^{\text {opt }}\right)$ of 1-3 were also estimated from the edge of the first of the absorption peak in solution (Table 1). By subtracting the optical band gap from the $\mathrm{IP}^{\mathrm{SS}}$, the $\mathrm{EA}^{\mathrm{SS}}$ was estimated. All spectra recorded in solid state are slightly redshifted in comparison with the spectra recorded in solution, which is consistent with some backbone-planarization and intermolecular polarization effects in solid state. The absorption band maximum of compound 1 in THF solution is redshifted from $404 \mathrm{~nm}$ to $420 \mathrm{~nm}$ in drop casted film. It is important to note that, the main absorption band of D102 dye used in this study is centered in the visible spectral region (Fig. 5). The three triphenylamine derivatives exhibit therefore no- or slight absorption overlap with the dye, thus avoiding harmful absorption competing between HTM versus the dye.

\subsection{Electrical \& photovoltaic properties}

In addition to thermal/morphological stabilities and a good Dye/HTM energy level matching, HTMs have to have good charge conductivity. Conductivity of the molecules was then studied using exactly the same doping conditions as used for solar cell devices with optimum concentrations of lithium bis(trifluoromethylsulfonyl)imide salt (Li-TFSI) plus 4-tert-butyl pyridine $(t \mathrm{BP})$. Fig. 6 shows the $I-V$ curves of films with two probes measurement.

Derived conductivity of compound $\mathbf{1}$ is $9.73 \times 10^{-5} \mathrm{~S} \mathrm{~m}^{-1}$, while compound 2 and 3 show relatively lower conductivities with $5.3 \times 10^{-7} \mathrm{~S} \mathrm{~m}^{-1}$ and $3.33 \times 10^{-6} \mathrm{~S} \mathrm{~m}^{-1}$ respectively, compared to the value $8.3 \times 10^{-4} \mathrm{~S} \mathrm{~m}^{-1}$ of Spiro-OMeTAD. ${ }^{11}$ These small conductivity values seem to stem from a collective effect of different electronic and structural factors: (i) the intramolecular reorganization energies are relatively large $(0.39$, 0.31 , and $0.38 \mathrm{eV}$ for 1-3 respectively, B3LYP/6-31G $(\mathrm{d}, \mathrm{p})$ level in
A

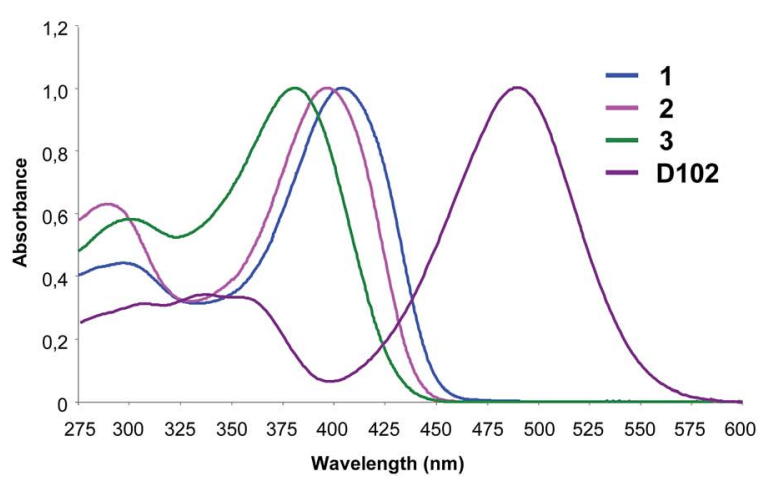

B

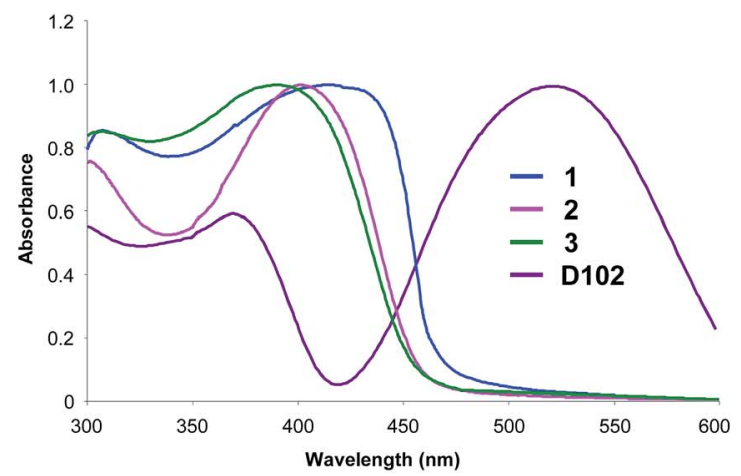

Fig. 5 UV-vis absorption spectra of 1-3 recorded in dilute THF solution (A) and thin films (B), the D102 UV-vis absorption spectra are also given in both figures. 


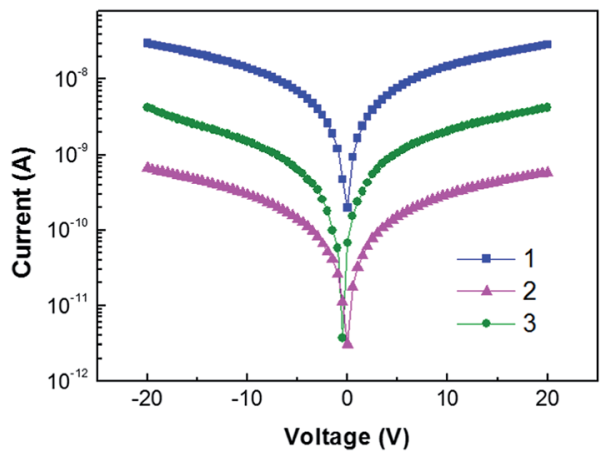

Fig. $6 \quad I-V$ curves of the doped films of compound 1-3 spin coated from chlorobenzene.

gas phase). (ii) The HOMOs have missing contributions from that DPA moieties (Fig. 4 and S4a $\dagger$ ), which are important for easy HOMO-HOMO electronic couplings between adjacent molecules. (iii) Due to the localization of the HOMOs inside the steric barrier created by the DPA moieties (Fig. 3 and $S 4 b \dagger$ ), the interaction between the TPA-Th moieties (the HOMO-bearing moieties) of adjacent molecules is expected to result in largedistance HOMO-HOMO couplings (see Fig. 4b-d). Addition of methyl groups into the thiophene ring induces distortions of the average $\pi$ plane due to steric hindrance and consequently may enlarge $\pi-\pi$ stacking distance, resulting in decreased charge transport ability of $\mathbf{2}$ and $\mathbf{3}$ as compared to $\mathbf{1}$.

The compounds 1-3 were subsequently incorporated in solid state D102-sensitized solar cells as hole transporting layers. $J-V$ curves under $100 \mathrm{~mW} \mathrm{~cm}{ }^{-2}$ AM $1.5 \mathrm{G}$ illumination are presented in Fig. 7. Best device performance parameters are listed in Table 2 .

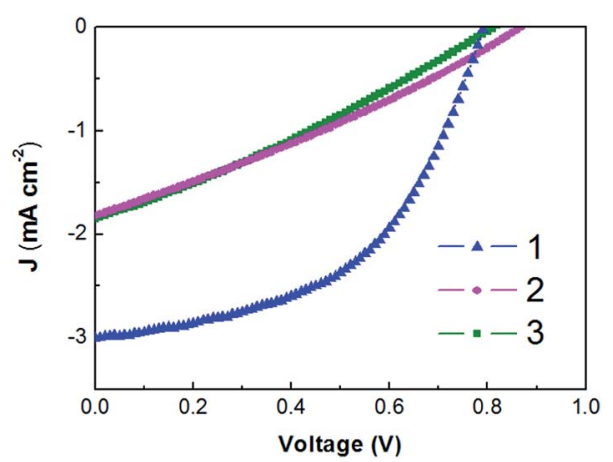

Fig. $7 \mathrm{~J}-V$ characteristics of ss-DSSCs using compound 1-3 as hole transport layers tested under $100 \mathrm{~mW} \mathrm{~cm}^{-2}$ AM 1.5 G illumination.

Table 2 Best device performance parameters of ss-DSSCs with compound $1-3$ as hole transport layers tested under $100 \mathrm{~mW} \mathrm{~cm}^{-2}$ AM 1.5 G illumination

\begin{tabular}{lllll}
\hline HTM & $J_{\text {sc }}\left(\mathrm{mA} \mathrm{cm}^{-2}\right)$ & $V_{\text {oc }}(\mathrm{V})$ & FF & PCE (\%) \\
\hline $\mathbf{1}$ & 3.0 & 0.79 & 0.51 & 1.20 \\
2 & 1.8 & 0.87 & 0.29 & 0.46 \\
3 & 1.85 & 0.81 & 0.29 & 0.44
\end{tabular}

Rather high values of $V_{\mathrm{oc}}$ were obtained from all the compounds, reaching even to $0.87 \mathrm{~V}$ for compound 2. Highest $J_{\text {sc }}\left(3.0 \mathrm{~mA} \mathrm{~cm}^{-2}\right)$ and fill factor $(51 \%)$ were achieved from the device based on compound 1, yielding PCE of 1.2\%. Both devices based on compound $\mathbf{2}$ and $\mathbf{3}$ gave low fill factor of only $29 \%$, as well as low $J_{\mathrm{sc}}$ of around $1.8 \mathrm{~mA} \mathrm{~cm}^{-2}$. Obviously, evidenced by our conductivity measurements, poor charge transport properties of these latter two compounds comparing to compound 1 hindered their ability to efficiently extract the photo-generated charges to the electrode.

It is interesting to look at performance stability of these new molecules. As reference, we also included benchmark hole transport molecule Spiro-OMeTAD in our study. Measurement of the devices was carried out in air, without encapsulation with continuous illuminations for more than two hours. The evolution of device performance parameters are shown in Fig. 8.

Unlike Spiro-OMeTAD device, the devices with all the new compounds did not evidence initial burn-out. On the contrary, all of them showed an initial enhancement in device performance. Decline in overall PCE mainly followed the trend in $J_{\mathrm{sc}}$ in all the devices, which takes into account all the processes from charge generation to collection in a cell. Notwithstanding rather low device performance of the devices based on these new
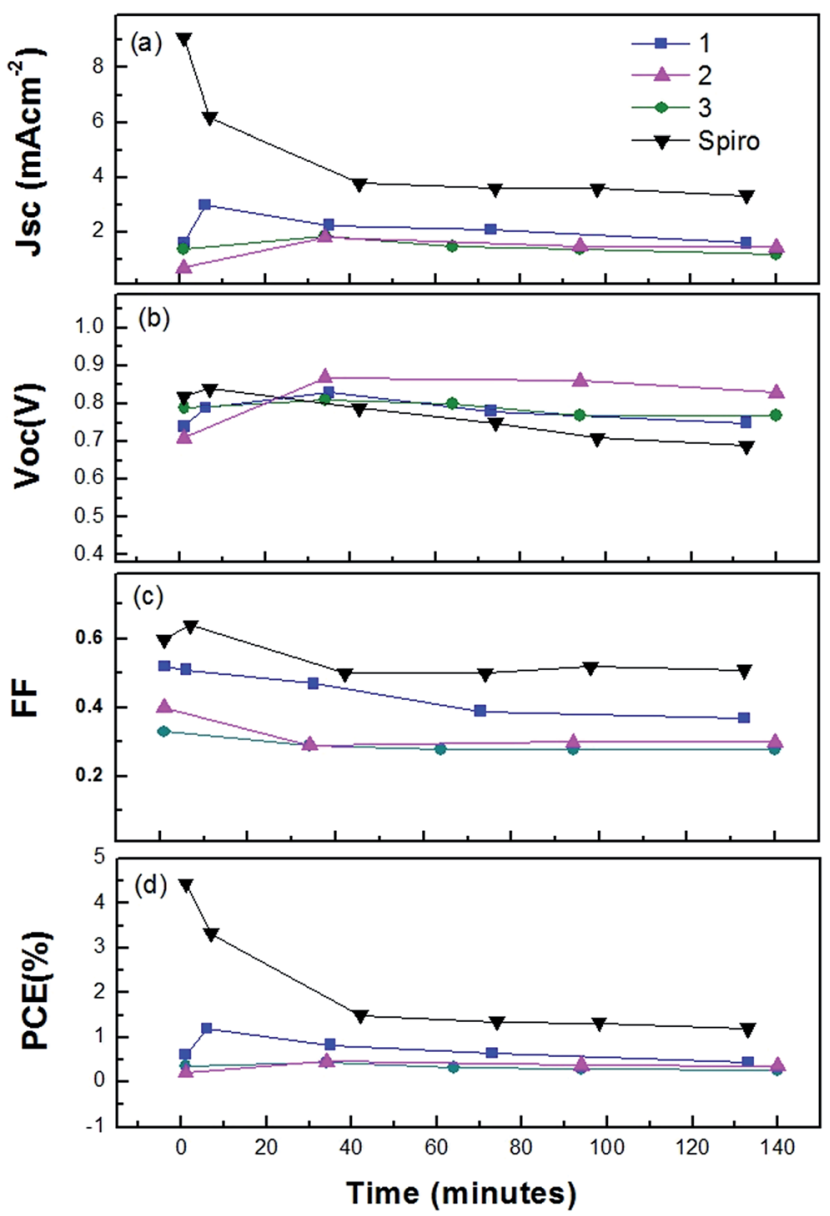

Fig. 8 Stability measurement of ss-DSSCs with 1-3 and Spiro-OMe$\mathrm{TAD}$ as hole transport layers. Devices were tested without sealing; in air under continuous illumination at $100 \mathrm{~mW} \mathrm{~cm}^{-2} \mathrm{AM} 1.5 \mathrm{G}$. 
molecules, they did show relatively high stability. When we compare the final performances with the highest values of these compounds, Spiro-OMeTAD retained $27 \%$ of PCE after 140 minutes under continuous illumination, while compound 1, 2 and 3 kept 51\%, 80\% and 57\% respectively.

\section{Conclusion}

In summary, novel di(4-methoxyphenyl)amino end-capped tri(4-thiophenylphenyl)amine based molecular glasses were synthesized and characterized in detail. The synthetic routes highlighted Pd-catalyzed reactions and allowed the preparation of highly soluble compounds using short multistep syntheses in relatively good yields. Thanks to their glass forming properties ( $T_{\mathrm{g}}$ varies from 74 to $99{ }^{\circ} \mathrm{C}$ ), these molecules are able to stay in amorphous state allowing the realization of a thin film with good contact with the nanostructured inorganic layer. Additionally, their HOMO energy levels are in good alignment with that of D102 dye rendering them suitable for use in solid-state dye-sensitized solar cell. Indeed, all these molecules yielded rather high $V_{\text {oc }}$, reaching even $0.87 \mathrm{~V}$ in solid state DSSC devices. Large variation in conductivity was observed when methyl groups were introduced in the thiophene ring. The compound without methyl group showed highest conductivity and best performance in ss-DSSC devices with PCE of 1.2\%. Comparison of device's stability of cells fabricated from HTM 1-3 with that fabricated from Spiro-OMeTAD was carried out in continuous illumination in air without encapsulation. It puts into evidence that these new molecules were rather stable keeping more than $50 \%$ of the highest performance (even $80 \%$ for compound 2 ) as compared to $27 \%$ in Spiro-OMeTAD device.

\section{Experimental section}

\subsection{General remarks}

Materials. All used chemicals and solvents were purchased from chemical companies and used as received, unless otherwise mentioned. Toluene was dried by distillation from sodium metal. Purification of products was performed by column chromatography on silica gel from Merck with a grain size of 0.04-0.063 mm (flash silica gel, Geduran Si 60) eluting with analytically pure solvents. For analytical thin layer chromatography, "60 F254" aluminium substrates coated with silica gel from Merck were used.

Instrumentation \& measurements. NMR $\left({ }^{1} \mathrm{H} \&{ }^{13} \mathrm{C}\right)$ spectra were recorded on a Bruker DPX-250 FT-NMR spectrometer. Chemical shifts ${ }^{\mathbf{1 8}}$ are given in ppm using the residual solvent signal as internal reference. High resolution mass spectrometry was performed by the Small Molecule Mass Spectrometry platform of IMAGIF (Centre de Recherche de Gif). UV-vis spectra were measured on a Jasco (V-570) UV-vis-NIR spectrophotometer. Thermogravimetric analysis (TGA) was carried out on a TA Instrument Q50 TGA under argon flow at a heating rate of $20^{\circ} \mathrm{C}$ $\min ^{-1}$. The temperature of thermal degradation $\left(T_{\mathrm{d}}\right)$ was measured at the point of $5 \%$ weight loss. Differential scanning calorimetry ${ }^{\mathbf{1 7}}$ was performed on a TA Instruments Q100 calorimeter, calibrated with indium and flushed with argon. The oxidation potential $\left(E_{\mathrm{ox}}\right)$ of the investigated compounds were measured in THF by cyclic voltammetry, scan rate $100 \mathrm{mV} \mathrm{s}^{-1}$, with tetrabutylammonium hexaperclorate $(0.1 \mathrm{M})$ as a supporting electrolyte in a standard one-compartment, threeelectrodes electrochemical cell under an argon stream using a "SP300 BioLogic" potentiostat. The working, reference and counter electrodes were platinum disk $(\varnothing=1 \mathrm{~mm})$, silver wire pseudo-reference, and stainless steel gauze electrodes, respectively. Ferrocene was used as an internal standard, and the potentials were referred to the reversible formal potential of this compound.

\subsection{Materials synthesis}

The synthesis of 1, $\mathbf{3}$ and their different intermediates have been reported in the literature previously. ${ }^{2}$

$N, N$-Bis(4-methoxyphenyl)-3-methylthiophen-2-amine. ${ }^{18}$ In a dry Schlenk equipped with magnetic stir bar and under argon, 2-bromo-3-methylthiophene $(0.5 \mathrm{~g}, 2.82 \mathrm{mmol})$, bis(4methoxyphenyl)amine (0.97 g, $4.23 \mathrm{mmol})$, palladium(II) acetate $(81 \mathrm{mg}, 0.36 \mathrm{mmol})$, sodium tert-butoxide (1.08 g, $11.3 \mathrm{mmol})$ and dry toluene $(10 \mathrm{~mL})$ were charged. The mixture was then degassed by argon purging for $30 \mathrm{~min}$. Tri-tert-butylphosphine (57 mg, $0.28 \mathrm{mmol}$ ) was added via syringe. The mixture was heated at $100{ }^{\circ} \mathrm{C}$ for 3 days and allowed to cool to room temperature. The mixture was diluted with toluene $(30 \mathrm{~mL})$, washed with water, dried over $\mathrm{MgSO}_{4}$ and concentrated. The crude product was purified by flash column chromatography eluting with $\mathrm{CH}_{2} \mathrm{Cl}_{2} /$ cyclohexane $(1: 3)$ to yield a pale yellow oil (630 mg, 68\%).

${ }^{1} \mathrm{H}$ NMR (250 MHz, $\mathrm{CDCl}_{3}, \delta$ ): 7.02-6.90 (m, 5H), 6.84-6.73 $(\mathrm{m}, 5 \mathrm{H}), 3.78(\mathrm{~s}, 6 \mathrm{H}), 1.94(\mathrm{~s}, 3 \mathrm{H}) .{ }^{13} \mathrm{C} \mathrm{NMR}\left(63 \mathrm{MHz}, \mathrm{CDCl}_{3}, \delta\right)$ : 156.2, 137.4, 135.6, 134.6, 129.2, 127.1, 123.4, 115.4, 56.2, 12.5.

5-Bromo- $\mathrm{N}, \mathrm{N}$-bis(4-methoxyphenyl)-3-methylthiophen-2-amine (6-Br). To a solution of $6(600 \mathrm{mg}, 1.84 \mathrm{mmol})$ in DMF $(20 \mathrm{~mL})$ was added $N$-bromosuccinimide $(328 \mathrm{mg}, 1.84 \mathrm{mmol})$ at $0{ }^{\circ} \mathrm{C}$. The solution was stirred for $3 \mathrm{~h}$ at room temperature. The total reaction was confirmed by TLC. The solution was poured into water $(20 \mathrm{~mL})$ and chloroform $(30 \mathrm{~mL})$ was added to the mixture. After phase separation, the aqueous layer was extracted with chloroform $(2 \times 20 \mathrm{~mL})$. The organic layer was washed with HCl $1 \mathrm{~N}$ solution $(4 \times 20 \mathrm{~mL})$, water $(2 \times 20 \mathrm{~mL})$, dried over $\mathrm{MgSO}_{4}$ and concentrated. The crude product was purified by flash chromatography on silica gel with $\mathrm{CH}_{2} \mathrm{Cl}_{2} /$ cyclohexane $(1: 3)$ as eluent to give pale yellow oil $(600 \mathrm{mg}, 80 \%)$.

${ }^{1} \mathrm{H}$ NMR $\left(250 \mathrm{MHz}, \mathrm{CDCl}_{3}, \delta\right): 6.95$ (d, $\left.J=8 \mathrm{~Hz}, 4 \mathrm{H}\right), 6.81$ (d, $J=7.8 \mathrm{~Hz}, 4 \mathrm{H}), 6.48(\mathrm{~s}, 1 \mathrm{H}), 3.80(\mathrm{~s}, 6 \mathrm{H}), 1.97$ (s, 3H). ${ }^{13} \mathrm{C} \mathrm{NMR}$ $\left(63 \mathrm{MHz}, \mathrm{CDCl}_{3}, \delta\right): 156.1,137.8,137.4,137.1,133.6,128.4$, 116.4, 113.1, 56.2, 11.8.

Tris(4-(5-(4,4'-dimethoxydiphenylamino)-4-methyl-2-thiophenyl)phenyl)amine. ${ }^{18}$ In a dry Schlenk equipped with magnetic stir bar and under argon, 6-Br $(0.5 \mathrm{~g}, 1.23 \mathrm{mmol})$, tris $(4-(4,4,5,5-$ tetramethyl-[1,3,2]dioxaborolane)phenyl)amine $(171 \mathrm{mg}$, $0.27 \mathrm{mmol})$, dry toluene $(80 \mathrm{~mL})$ and $\mathrm{K}_{2} \mathrm{CO}_{3} 2 \mathrm{M}$ solution $(20 \mathrm{~mL})$ were charged. The mixture was then degassed by argon purging for $30 \mathrm{~min}$. Aliquat 336 (3 drops) and $\mathrm{Pd}\left(\mathrm{PPH}_{3}\right)_{4}(59 \mathrm{mg})$ were added. The mixture was heated at $90{ }^{\circ} \mathrm{C}$ for 3 days and allowed to 
cool to room temperature. The mixture was diluted with toluene $(30 \mathrm{~mL})$ and after phase separation; the organic layer was washed with brine $(2 \times 20 \mathrm{~mL})$, water $(2 \times 20 \mathrm{~mL})$, dried over $\mathrm{MgSO}_{4}$ and concentrated. The crude product was purified by column chromatography eluting with $\mathrm{CH}_{2} \mathrm{Cl}_{2} /$ cyclohexane $(7: 3)$ to yield a pale yellow solid (250 $\mathrm{mg}, 76 \%$ ).

${ }^{1} \mathrm{H}$ NMR (250 MHz, $\left.\mathrm{CDCl}_{3}, \delta\right): 7.42(\mathrm{~d}, J=8.5 \mathrm{~Hz}, 6 \mathrm{H}), 7.05$ $(\mathrm{d}, J=8 \mathrm{~Hz}, 12 \mathrm{H}), 6.98(\mathrm{~d}, J=8.4 \mathrm{~Hz}, 6 \mathrm{H}), 6.88(\mathrm{~d}, J=7.9 \mathrm{~Hz}$, 12H), 6.78 (s, 3H), $3.83(\mathrm{~s}, 18 \mathrm{H}), 2.08$ (s, 9H). HRMS (ESI+): calculated for $\mathrm{M}^{+}: 1214.4145$, found: 1214.4116 .

\subsection{Device fabrication and characterization}

For conductivity measurement, the doped solutions used for DSSC devices were spin coated on glass substrate. Hole transport molecules were dissolved in chlorobenzene $(200 \mathrm{mg}$ $\mathrm{mL}^{-1}$ ), by heating and stirring the solution at $80{ }^{\circ} \mathrm{C}$ for 30 minutes. Optimized doping concentrations of lithium bis(trifluoromethylsulfonyl)imide salt (Li-TSFI) dissolved in acetonitrile $\left(170 \mathrm{mg} \mathrm{mL}^{-1}\right)$ and 4-tert-butylpyridine $(t \mathrm{Bp})$ are $1: 19.3$ and $1: 40.8$ in volume ratio respectively. Au metal stripes with width of $0.05 \mathrm{~mm}$ and length of $2.5 \mathrm{~mm}$ were deposited. Keithley 4200 semiconductor analyser was used to record $I-V$ curves. For ss-DSSC devices, fluorine doped tin oxide (FTO) glasses were used as working electrode. One third Part of FTO was etched away using $\mathrm{HCl}$ and $\mathrm{Zn}$ powder and cleaned by consecutive sonication in acetone, ethanol and isopropanol for 15 minutes and dried. The substrates were then treated in UV-ozone for 15 minutes. A thin compact layer of $\mathrm{TiO}_{x}$ was deposited using spin coating from the solution of titanium(IV) isopropoxides (TIPP) diluted in ethanol at the concentration of $0.05 \mathrm{M}$ and $\mathrm{HCl}$ was added in order to have a water to TIPP molar ratio $\left(r_{\mathrm{w}}\right)$ of 0.82 and a $\mathrm{pH}$ of 1.9 . The samples were annealed at $450{ }^{\circ} \mathrm{C}$ for 20 minutes with subsequent cooling at $70{ }^{\circ} \mathrm{C}$. The films were then treated with $\mathrm{TiCl}_{4}$ in water $(220 \mu \mathrm{L} / 100 \mathrm{~mL})$ for 30 minutes at $70^{\circ} \mathrm{C}$ followed by rinsing with water and heating again to $450{ }^{\circ} \mathrm{C}$ for 20 minutes. Mesoporous $\mathrm{TiO}_{2}$ films were spin coated on top of the compact layer using a widely available $\mathrm{Ti}$ nanooxide paste (SOLARONIX) diluting in ethanol. The films were then slowly heated to $500{ }^{\circ} \mathrm{C}$ followed by again $\mathrm{TiCl}_{4}$ treatment. The mesoporous $\mathrm{TiO}_{2}$ electrodes were placed for 1 hour in organic dye (D102) solution $\left(0.15 \mathrm{mg} \mathrm{mL}^{-1}\right)$ in a mixture of acetonitrile and tertbutanol $(1: 1)$. The dye coated mesoporous films were rinsed in ethanol and dried in air overnight. $40 \mu \mathrm{L}$ doped solution was deposited onto each film at room temperature and left for 1 minute before spin coating at $3500 \mathrm{RPM}$ for $20 \mathrm{~s}$ in air. After spin coating, the films were kept for 24 hours in air. A $100 \mathrm{~nm}$ of $\mathrm{Ag}$ was deposited by thermal evaporation to complete the device structure. The device area, as defined by the overlap between the ITO and Ag electrodes, was $8.6 \mathrm{~mm}^{2}$. Currentvoltage $(J-V)$ characteristics of the devices were examined in air under illumination of an AM 1.5 set at $1000 \mathrm{~W} \mathrm{~m}^{-2}$ with a calibrated silicon radiometer (Akoos). Stability of the ss-DSSCs without sealing was tested under continuous illumination in air for 2 hours.

\subsection{Computational details}

All the calculations were performed in the frame of DFT ${ }^{\mathbf{1 9}}$ theory employing the B3LYP ${ }^{20}$ functional with Gaussian 09 program $^{21}$ The geometry optimizations for all the molecules were carried out without symmetry constraints by using the 6-31G(d,p) basis set, followed by frequency calculations. The absorption spectra of the molecules were calculated by mean of time dependent density functional theory method (TDDFT) ${ }^{22}$ with the 6-31G(d,p) basis set. The theoretical absorption bands were obtained by considering a band half-width at half-maximum of $0.2 \mathrm{eV} .^{23}$

\section{Acknowledgements}

The authors thank the Agence Nationale de la Recherche (ANR) for funding (FMOCSOLE Blanc SIMI 92010 project).

\section{References and notes}

1 J. Roncali, P. Leriche and P. Blanchard, Adv. Mater., 2014, 26, 3821.

2 T.-T. Bui, L. Beouch, X. Sallenave and F. Goubard, Tetrahedron Lett., 2013, 54, 4277.

3 T.-T. Bui and F. Goubard, Mater. Tech., 2013, 101, 102; T.-T. Bui and F. Goubard, EPJ Photovoltaics, 2013, 4, 40402.

4 G. Puckyte, B. Schmaltz, A. Tomkeviciene, M. Degbia, J. V. Grazulevicius, H. Melhem, J. Bouclé and F. Tran-Van, J. Power Sources, 2013, 233, 86; A. Michaleviciute, M. Degbia, A. Tomkeviciene, B. Schmaltz, E. Gurskyte, J. V. Grazulevicius, J. Bouclé and F. Tran-Van, J. Power Sources, 2014, 253, 230.

5 Y. Shirota, J. Mater. Chem., 2005, 15, 75; R. R. Reghu, J. V. Grazulevicius, J. Simokaitiene, A. Miasojedovas, K. Kazlauskas, S. Jursenas, P. Data, K. Karon, M. Lapkowski, V. Gaidelis and V. Jankauskas, J. Phys. Chem. C, 2012, 116, 15878.

6 U. Bach, D. Lupo, P. Comte, J. E. Moser, F. Weissortel, J. Salbeck, H. Spreitzer and M. Gratzel, Nature, 1998, 395, 583.

7 J. Burschka, A. Dualeh, F. Kessler, E. Baranoff, N.-L. CeveyHa, C. Yi, M. K. Nazeeruddin and M. Gratzel, J. Am. Chem. Soc., 2011, 133, 18042.

8 H. Zhou, Q. Chen, G. Li, S. Luo, T.-b. Song, H.-S. Duan, Z. Hong, J. You, Y. Liu and Y. Yang, Science, 2014, 345, 542. 9 T. Leijtens, J. Lim, J. Teuscher, T. Park and H. J. Snaith, Adv. Mater., 2013, 25, 3227.

10 B. Xu, E. Sheibani, P. Liu, J. Zhang, H. Tian, N. Vlachopoulos, G. Boschloo, L. Kloo, A. Hagfeldt and L. Sun, Adv. Mater., 2014, 26, 6629; P. Qin, S. Paek, M. I. Dar, N. Pellet, J. Ko, M. Grätzel and M. K. Nazeeruddin, J. Am. Chem. Soc., 2014, 136, 8516; J. Xiao, L. Han, L. Zhu, S. Lv, J. Shi, H. Wei, Y. Xu, J. Dong, X. Xu, Y. Xiao, D. Li, S. Wang, Y. Luo, X. Li and Q. Meng, RSC Adv., 2014, 4, 32918.

11 T.-T. Bui, S. K. Shah, M. Abbas, X. Sallenave, G. Sini, L. Hirsch and F. Goubard, ChemNanoMat, 2015, DOI: 10.1002/cnma.201500014. 
12 J. Liu, Y. Wu, C. Qin, X. Yang, T. Yasuda, A. Islam, K. Zhang, W. Peng, W. Chen and L. Han, Energy Environ. Sci., 2014, 7, 2963; L. Zheng, Y.-H. Chung, Y. Ma, L. Zhang, L. Xiao, Z. Chen, S. Wang, B. Qua and Q. Gong, Chem. Commun., 2014, 50, 11196.

13 Z. Ning and H. Tian, Chem. Commun., 2009, 5483; H. Kageyama, H. Ohishi, M. Tanaka, Y. Ohmori and Y. Shirota, Adv. Funct. Mater., 2009, 19, 3948; H. Kageyama, H. Ohishi, M. Tanaka, Y. Ohmori and Y. Shirota, Appl. Phys. Lett., 2009, 94, 063304; S. Roquet, A. Cravino, P. Leriche, O. Aleveque, P. Frere and J. Roncali, J. Am. Chem. Soc., 2006, 128, 3459.

14 N. Metri, X. Sallenave, L. Beouch, C. Plesse, F. Goubard and C. Chevrot, Tetrahedron Lett., 2010, 51, 6673; J. Zhang, X. Sallenave, T.-T. Bui, F. Dumur, P. Xiao, B. Graff, D. Gigmes, J. P. Fouassier and J. Lalevée, Macromol. Chem. Phys., 2015, 216, 218-227.

15 N. Metri, X. Sallenave, C. Plesse, L. Beouch, P.-H. Aubert, F. Goubard, C. Chevrot and G. Sini, J. Phys. Chem. C, 2012, 116, 3765; A. K. Diallo, N. Metri, F. Brunel, X. Sallenave, F. Goubard, O. Margeat, J. Ackermann and C. VidelotAckermann, Synth. Met., 2013, 184, 35.

16 A. Sakalyte, J. Simokaitiene, A. Tomkeviciene, J. Keruckas, G. Buika, J. V. Grazulevicius, V. Jankauskas, C.-P. Hsu and C.-H. Yang, J. Phys. Chem. C, 2011, 115, 4856; V. Mimaite, J. Ostrauskaite, D. Gudeika, J. V. Grazulevicius and V. Jankauskas, Synth. Met., 2011, 161, 1575.

17 T. Arita, J. Yoo, Y. Ueda and T. Adschiri, Nanoscale, 2010, 2, 689.

18 M. Pupek, D. Krzyzanowska-Golab, T. Dyla, A. LemanskaPerek, R. Jankowska and I. Katnik-Prastowska, Clin. Biochem., 2009, 42, 654.
19 W. Kohn and L. Sham, Phys. Rev., 1965, 140, A1133.

20 C. T. Lee, W. T. Yang and R. G. Parr, Phys. Rev. B: Condens. Matter Mater. Phys., 1988, 37, 785; A. D. Becke, J. Chem. Phys., 1993, 98, 5648.

21 M. J. Frisch, G. W. Trucks, H. B. Schlegel, G. E. Scuseria, M. A. Robb, J. R. Cheeseman, G. Scalmani, V. Barone, B. Mennucci, G. A. Petersson, H. Nakatsuji, M. Caricato, X. Li, H. P. Hratchian, A. F. Izmaylov, J. Bloino, G. Zheng, J. L. Sonnenberg, M. Hada, M. Ehara, K. Toyota, R. Fukuda, J. Hasegawa, M. Ishida, T. Nakajima, Y. Honda, O. Kitao, H. Nakai, T. Vreven, J. Montgomery, J. E. Peralta, F. Ogliaro, M. Bearpark, J. J. Heyd, E. Brothers, K. N. Kudin, V. N. Staroverov, T. Keith, R. Kobayashi, J. Normand, K. Raghavachari, A. Rendell, J. C. Burant, S. S. Iyengar, J. Tomasi, M. Cossi, N. Rega, J. M. Millam, M. Klene, J. E. Knox, J. B. Cross, V. Bakken, C. Adamo, J. Jaramillo, R. Gomperts, R. E. Stratmann, O. Yazyev, A. J. Austin, R. Cammi, C. Pomelli, J. W. Ochterski, R. L. Martin, K. Morokuma, V. G. Zakrzewski, G. A. Voth, P. Salvador, J. J. Dannenberg, S. Dapprich, A. D. Daniels, O. Farkas, J. B. Foresman, J. V. Ortiz, J. Cioslowski and D. J. Fox, Gaussian 09, Revision B.01, Gaussian Inc., Wallingford CT, 2009.

22 M. E. Casida, C. Jamorski, K. C. Casida and D. R. Salahub, J. Chem. Phys., 1998, 108, 4439; R. Bauernschmitt and R. Ahlrichs, Chem. Phys. Lett., 1996, 256, 454; E. K. U. Gross and W. Kohn, Adv. Quantum Chem., 1990, 21, 255; E. K. U. Gross and W. Kohn, Phys. Rev. Lett., 1985, 55, 2850; E. Runge and E. K. U. Gross, Phys. Rev. Lett., 1984, 52, 997.

23 R. Dennington, T. Keith and J. Millam, V. GaussView, Semichem Inc., Shawnee. 